\title{
Yield improvement through female homosexual hybrids and sex genetics of sweet gourd (Momordica cochinchinensis Spreng.)
}

\author{
S. K. Sanwal • Marcin Kozak · Sanjeev Kumar • \\ B. Singh $\cdot$ B. C. Deka
}

Received: 15 April 2010/Revised: 10 December 2010/Accepted: 29 December 2010/Published online: 18 January 2011

(C) The Author(s) 2011. This article is published with open access at Springerlink.com

\begin{abstract}
The present research aimed to evaluate the effect of silver nitrate $\left(\mathrm{AgNO}_{3}\right)$ on sex modification in sweet gourd (Momordica cochinchinensis Spreng.), and to explore the possibility of sexual crossing between two genetically female plants. Spray applications of $\mathrm{AgNO}_{3}$ on 30 days' old female plants induced hermaphrodite flowers. Male plants were insensitive to the $\mathrm{AgNO}_{3}$ sprays. Application of $500 \mathrm{mg} / \mathrm{l} \mathrm{AgNO}_{3}$ on female plants produced the maximum proportion of induced hermaphrodite flowers. Hermaphrodite flowers appeared 17-21 days after $\mathrm{AgNO}_{3}$ spray and continued up to 8-17 days, depending upon the concentration of $\mathrm{AgNO}_{3}$. Pollen grain viability of induced hermaphrodite flowers $(93.5 \%)$ was similar to pollen grain viability of normal male (95.0\%) flowers. Because of higher fruit weight, progenies from female homosexual cross recorded higher yield. The hybrids from such crosses produced only female plants while the hybrids between female and normal male segregated into male and female in an equal proportion, indicating that sex in sweet gourd is controlled by a single factor, male being heterozygous
\end{abstract}

Communicated by J. Van Huylenbroeck.

S. K. Sanwal · S. Kumar · B. Singh

Indian Institute of Vegetable Research,

P. B. 01, P. O. Jakhini (Shahanshahpur),

Varanasi 221305, India

M. Kozak ( $\square)$

Department of Experimental Design and Bioinformatics,

Warsaw University of Life Sciences, Warsaw, Poland

e-mail: nyggus@gmail.com

B. C. Deka

ICAR Research Complex for NEH Region,

Umiam, Meghalaya 793103, India and female being homozygous recessive. Through this technique, elite characters of female genotypes could be combined into a single plant.

Keywords Growth regulators $\cdot$ Female $\times$ female hybrids · Dioecious plants

\section{Introduction}

Sweet gourd (Momordica cochinchinensis Spreng.) is an underutilized perennial dioecious cucurbit vegetable, highly valued for its nutritional and medicinal qualities and wide range of adaptability. Traditionally, it is propagated using its swollen tubers. Among the cucurbitaceous vegetables grown during summer season, sweet gourd fetches a high price. Dioecious condition, unavailability of improved varieties, difficulties in propagation by seeds due to dormancy, low multiplication rate and unpredictable sex ratio in seed-based populations are major bottlenecks in increasing the yield potential of this species (Puzari 1999).

In dioecious plants, assessment of yield performance of a female line using male plants is difficult, since male plants do not produce fruits, and their utility ends with supply of pollen for fruit set on female plants. This reduces the chance of making a cross with yield advantage of the hybrid over its female parent. Sex modification in plants can often be achieved by application of plant growth regulators (Das and Mukherjee 1986; Marchetti et al. 1992). The critical role of exogenous and endogenous growth regulators such as cytokinins, gibberellins, ethylene and auxins on plant sex determination has been investigated in various plant systems, like Mecurialis spp. (Durand and Durand 1991), and M. charantia (Thomas 2008). Selffertilization in female plants of dioecious species has been 
made possible by inducing hermaphrodite flowers (Ali et al. 1991; Hossain et al. 1996).

In the case of kakrol (M. dioica), crossing between two female genotypes (homosexual) is possible through the induction of hermaphrodite flowers in one or both of the female plants by spray application of $\mathrm{AgNO}_{3}$ (Ali et al. 1991; Rajput et al. 1994; Hossain et al. 1996). In the case of cucumber, seeds obtained from gynoecious lines pollinated with male flowers (induced through $\mathrm{AgNO}_{3}$ spray) have the tendency to produce only female plants (Atsmon and Tabbak 1979; Hallidri 2004).

Robinson and Decker-Walters (1997) suggested that in melons, genes $a$ (andromonoecious) and $g$ (gynomonoecious) interact to influence sex expression. Hossain et al. (1996) reported that sex in $M$. dioica is controlled by a single factor, male being heterozygous and female homozygous recessive. Similarly, in the case of $M$. charantia, gynoecism has been reported to be under the control of a single recessive gene (Ram et al. 2006; Behera et al. 2009).

Thus, recombination of desirable characters of parents in a single plant can be done through intergenotypic crossing between two female genotypes. Selection of highyielding lines from such female homosexual hybrids may lead to establishing a variety within a short period, because sweet gourd is propagated vegetatively. The present study was thus undertaken to evaluate the effects of $\mathrm{AgNO}_{3}$ concentration on sex modification in order to understand the mechanism of sex genetics, and to explore the possibility of sexual crossing between two genetically female plants.

\section{Materials and methods}

Planting material and field evaluation

Field experiments were conducted during March to May of 2007-2008 and 2008-2009 at the ICAR Research Complex for North Eastern Hills Region, Umiam, Meghalaya, India. The experimental site is located at $26^{\circ} \mathrm{N}$ latitude and $92^{\circ} \mathrm{E}$ longitude, with an elevation of $950 \mathrm{~m}$ above mean sea level. During the experiment period, the temperature was between 12.6 and $30^{\circ} \mathrm{C}$, relative humidity was $41-94 \%$, and total rainfall was $223.7 \mathrm{~mm}$. Planting material consisted of two female genotypes and one male genotype. Female genotypes were selected on the basis of their yield potential. Tuberous roots of 100 female and 12 male plants were planted in pots. After sprouting, each plant was transplanted into the field; the experiment was arranged in a completely randomized block design (CRBD) with three replications. The plant-to-plant and row-to-row distances were kept at $1.5 \mathrm{~m}$. For a good crop growth, $50 \mathrm{~kg}$ nitrogen $(\mathrm{N}), 40 \mathrm{~kg}$ phosphorus $(\mathrm{P})$ and $60 \mathrm{~kg}$ potassium $(\mathrm{K})$ was applied; full quantity of $\mathrm{P}$ and $\mathrm{K}$ and half the quantity of $\mathrm{N}$ was applied as a basal dose and the remaining $\mathrm{N}$ was applied in two split doses at 30 and 60 days after planting. Irrigation was carried out at weekly intervals. The recommended intercultural practices were followed to have a good crop stand (Ram et al. 2002).

\section{Silver nitrate spray and hybridization}

The male and female vines were sprayed with different concentrations of $\mathrm{AgNO}_{3}(100,200,300,400,500,700$, 900 , and 1,000 mg/l) at pre-flowering stage (about 30 days after plant emergence). Spraying was done until the solution ran off the shoots. In control, male or female vines were not sprayed. The total number of flowers of different sex types, i.e., male (Fig. 1a), female (Fig. 1b), and hermaphrodite (Fig. 1c), per plant was counted. Crossing among flowers of different sex types (male, female and induced hermaphrodite) and selfing within and between the plants of the same clone was done after initiation of hermaphrodite flowers. On each plant, total number of flowers of each sex (male, female and hermaphrodite) was counted. Pollen grain viability of the normal male and induced hermaphrodite flowers was assessed by tetrazolium test

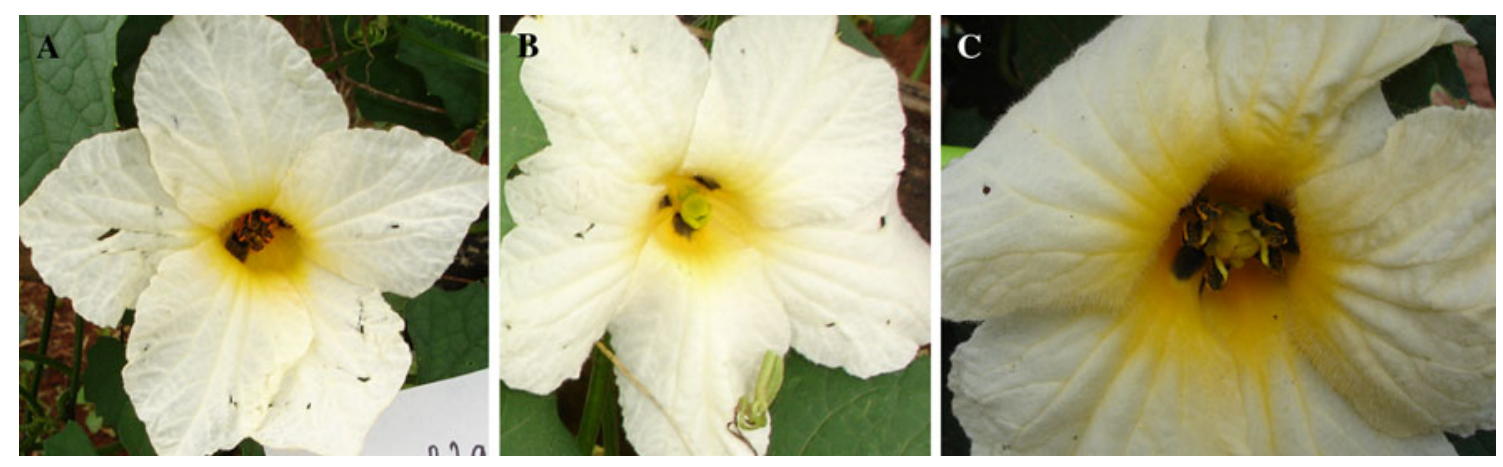

Fig. 1 A male (a), female (b), and an induced hermaphrodite (c) flower of sweet gourd 
(Heslop-Harrison and Heslop-Harrison 1970). Fully mature fruits were harvested and seeds were collected.

\section{Hybrid performance}

Hybrid seeds of the female homosexual and heterosexual crosses were sown in pots in February 2008. Forty-five days' old germinated hybrid seedlings as well as the parental female plants (raised through tuberous roots) were transplanted into the field in March 2008. The experiment was laid in CRBD with three replications; data was recorded on three random plants from each replication. At the flowering stage, sex of hybrid plants was recorded and genetic control of the sex expression was determined. Data were also recorded on percentage of fruit set on the basis of number of crosses made and actual fruit set, number of fruits per plant and individual fruit weight. Number of seeds per fruit was counted from five random fruits per plant and averaged. Germination percentage was calculated by sowing a known number of seeds and recording the number of germinated seedlings.

\section{Statistical analysis}

Regression analysis was employed to study the influence of $\mathrm{AgNO}_{3}$ concentration on the traits considered, based on raw data. The effect of nature of cross on fruit weight, yield $(\mathrm{kg})$, number of seeds per fruit, fruit set per plot and number of fruits per plant was studied through linear models, while the effects on pollen viability and seed germination were studied through generalized linear models with the binomial distribution for the errors and log link function (Agresti 2002). The goodness of fit of the models was checked graphically. In case of significant differences among the natures of crosses, Tukey's contrasts for the corresponding linear or generalized linear model in the multcomp package of $\mathrm{R}$ were employed (Hothorn et al. 2008). No adjustment for multiple testing was applied (Kozak 2009). The analyses were performed with $R$ (R Development Core Team 2010), and the plots were constructed with the lattice package of R (Sarkar 2008).

\section{Results and discussion}

Standardization of $\mathrm{AgNO}_{3}$ concentration

Only female vines produced hermaphrodite flowers (Fig. 1c) when treated with $\mathrm{AgNO}_{3}$, whereas male vines were insensitive to the chemical treatment. More importantly, the proportion of induced hermaphrodite flowers on female plants was highest (15) when treated with $500 \mathrm{mg} / \mathrm{l}$ $\mathrm{AgNO}_{3}$ (Fig. 2a, b). With an increase in concentration
(700 $\mathrm{mg} / \mathrm{l} \mathrm{AgNO}_{3}$ ), there was a sharp decline (about 10) in the proportion of induced hermaphrodite flowers (Fig. 2b). Higher concentrations of $\mathrm{AgNO}_{3}$ also exhibited senescence and wilting of vines. Spraying with $\mathrm{AgNO}_{3}$ below $500 \mathrm{mg} / \mathrm{l}$ also reduced the induction of hermaphrodite flowers (Fig. 2b). The maximum number of female flowers (39) was recorded in the untreated vines (Fig. 2c). These results are in agreement with the findings of Rajput et al. (1994) in kakrol (M. dioica).

There was a wide variation in number of hermaphrodite flowers due to spray of $\mathrm{AgNO}_{3}$. The maximum (15 flowers) was at a concentration of $500 \mathrm{mg} / \mathrm{l}$ while the minimum (6 flowers) on 100 and $200 \mathrm{mg} / \mathrm{l}$. The onset of hermaphrodite flowers started 17-21 days after $\mathrm{AgNO}_{3}$ spray and continued up to 8-21 days, depending on the $\mathrm{AgNO}_{3}$ concentration (Fig. 3a). Normal female flowers started to open after the completion of hermaphrodite flowers. Female flower opened after 16 days in control (no $\mathrm{AgNO}_{3}$ spray) while it took 38 days in treatment with $500 \mathrm{mg} / \mathrm{l}$ $\mathrm{AgNO}_{3}$ (Fig. 3b). The reason for this may be that the silver nitrate is known to be a potential inhibitor of ethylene action (Ockendon and Clenagham 1993; Ghaemi et al. 1994), suppressing the development of female flowers and inducing the male sex in genetically female plant (Beyer 1976; Atsmon and Tabbak 1979; Takahashi and Jaffe 1984). The effect of silver nitrate on male flower induction is well documented in cucumber, Cucumis sativus (Stankovic and Prodanovic 2002). The results of present study are in agreement with the observations made by Ali et al. (1991) and Rajput et al. (1994) in kakrol (M. dioica).

Pollen grain viability and hybrid seed germination

Pollen grain viability of induced hermaphrodite flowers was similar to that with normal male (Table 2). Similar results were reported by Ali et al. (1991). The per cent fruit set in homosexual crossing was smaller (88.5\%) compared to heterosexual crossing (91.1\%; Table 2). Fruit setting due to self-fertilization was recorded to be very low $(33.4 \%)$. The number of seeds and seed germination per cent in self and homosexual cross were smaller than those for the parents and heterosexual cross (Table 2). Very poor germination (16.4\%) was recorded in selfed seeds (female $\times$ induced male of the same plant), which may be attributed to inbreeding depression due to selfing in this strictly cross-pollinated species. A similar observation has been made for M. dioica (Hossain et al. (1996).

Performance of parents and their $F_{1}$ progenies

The number of fruits per plant was the highest in parents (32.8) and their hetero- (32.1) and homosexual (30.7) $F_{1}$ 
Fig. 2 Polynomial relationships between flower traits of plants and $\mathrm{AgNO}_{3}$ concentration (refer to Table 1 for the regression equations)
Fig. 3 Polynomial

relationships between days for induction of hermaphrodite and female flowers after spray application of $\mathrm{AgNO}_{3}$ (refer to Table 1 for the regression equations)
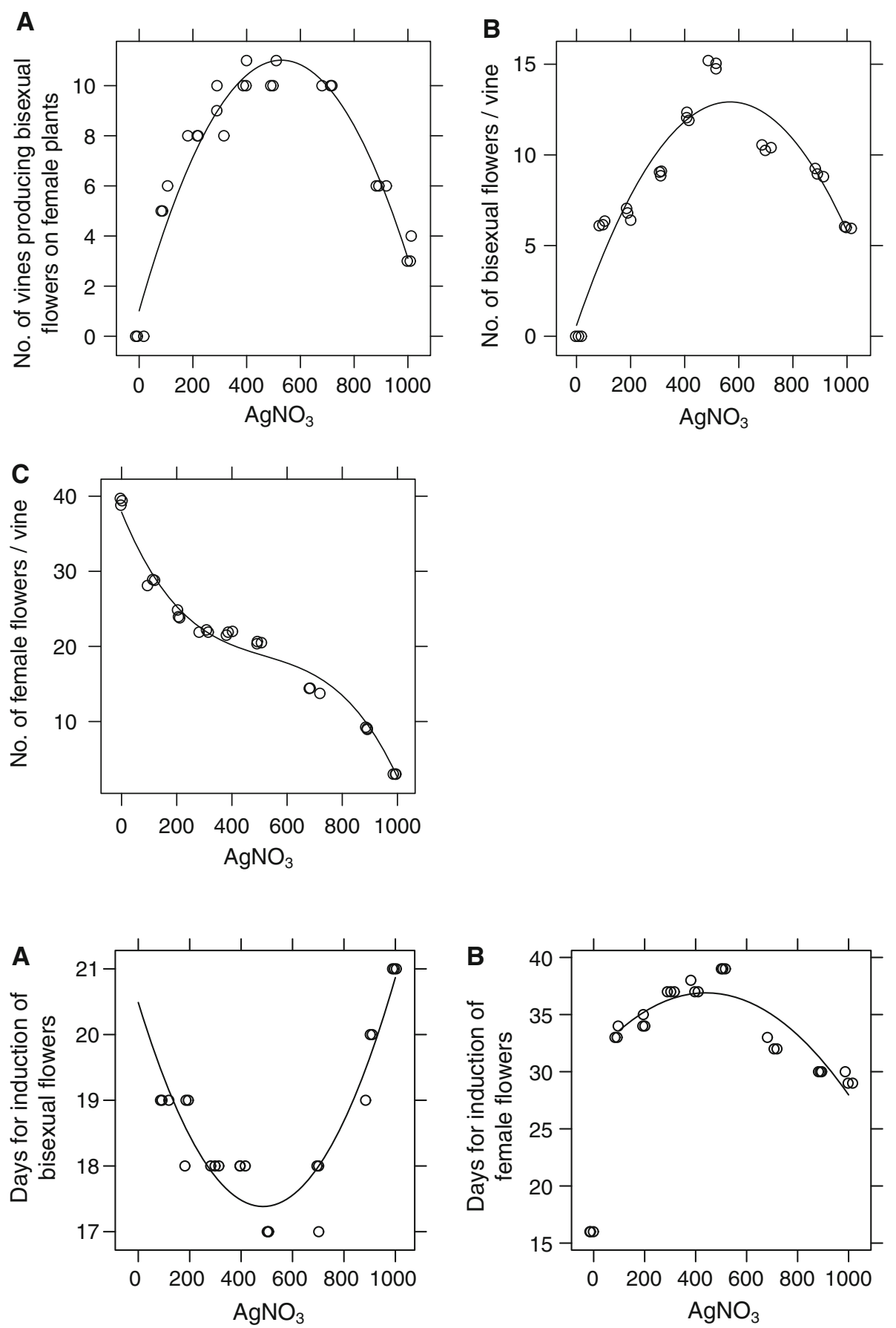

Table 1 Influence of $\mathrm{AgNO}_{3}$ concentration on morphological traits analyzed through polynomial regression

\begin{tabular}{llll}
\hline Dependent trait & Polynomial regression equation & $R_{\text {adj }}^{2}$ \\
\hline No. of vines producing bisexual flowers on female plants & $1.014+0.0038 \mathrm{AgNO}_{3}-0.000036 \mathrm{AgNO}_{3}^{2}$ & 0.952 \\
No. of bisexual flowers per vine & $0.602+0.043 \mathrm{AgNO}_{3}-0.000038 \mathrm{AgNO}_{3}^{2}$ & 0.893 \\
No. of female flowers per vine & $3.79-0.089 \mathrm{AgNO}_{3}+0.00015 \mathrm{AgNO}_{3}^{2}-9.72$ & $10^{-8} \mathrm{AgNO}_{3}^{3}$ & 0.980 \\
Days for induction of bisexual flowers & $2.049-0.013 \mathrm{AgNO}_{3}+0.000013 \mathrm{AgNO}_{3}^{2}$ & 0.871 \\
Days for induction of female flowers & $3.137+0.025 \mathrm{AgNO}_{3}-0.000029 \mathrm{AgNO}_{3}^{2}$ & 0.785 \\
\hline
\end{tabular}

The regression lines are presented in Figs. $2 \mathrm{a}-\mathrm{c}$ and $3 \mathrm{a}$, b. $R_{\mathrm{adj}}^{2}$, stands for the adjusted coefficient of determination 
Table 2 Effects of nature of cross on yield-contributing traits

\begin{tabular}{llllllll}
\hline $\begin{array}{l}\text { Nature of } \\
\text { cross }\end{array}$ & $\begin{array}{l}\text { Pollen } \\
\text { viability }(\%)\end{array}$ & $\begin{array}{l}\text { Fruit set } \\
(\%)\end{array}$ & $\begin{array}{l}\text { Seed } \\
\text { germination }(\%)\end{array}$ & $\begin{array}{l}\text { Fruit } \\
\text { weight }(\mathrm{g})\end{array}$ & $\begin{array}{l}\text { Yield per } \\
\text { plant }(\mathrm{kg})\end{array}$ & $\begin{array}{l}\text { No. of seeds } \\
\text { per fruit }\end{array}$ & $\begin{array}{l}\text { No. of fruit } \\
\text { per plant }\end{array}$ \\
\hline Selfing & $94.0 \mathrm{a}$ & $33.4 \mathrm{a}^{1}$ & $16.4 \mathrm{a}$ & $66.5 \mathrm{a}$ & $0.95 \mathrm{a}$ & $21.0 \mathrm{a}$ & $14.4 \mathrm{a}$ \\
Heterosexual & $95.0 \mathrm{a}$ & $91.1 \mathrm{~b}$ & $41.5 \mathrm{~b}$ & $68.0 \mathrm{ab}$ & $2.18 \mathrm{~b}$ & $27.0 \mathrm{~d}$ & $32.1 \mathrm{c}$ \\
Homosexual & $93.5 \mathrm{a}$ & $88.5 \mathrm{~b}$ & $37.5 \mathrm{~b}$ & $74.5 \mathrm{c}$ & $2.28 \mathrm{c}$ & $24.6 \mathrm{~b}$ & $30.7 \mathrm{~b}$ \\
Parents & $94.9 \mathrm{a}$ & $91.0 \mathrm{~b}$ & $42.1 \mathrm{~b}$ & $68.8 \mathrm{~b}$ & $2.25 \mathrm{bc}$ & $25.4 \mathrm{c}$ \\
\hline
\end{tabular}

${ }^{1}$ Means with different letters in a column are significantly different at $P<0.05$, according to Tukey's contrasts for the corresponding linear or generalized linear model

Table 3 Sex expression in progeny from selfing, hetero- and homosexual cross

\begin{tabular}{|c|c|c|c|}
\hline \multirow[t]{2}{*}{ Nature of cross } & \multicolumn{2}{|c|}{ Number of male/female plants } & \multirow{2}{*}{$\begin{array}{l}\text { Expressed ratio } \\
\text { Female:male }\end{array}$} \\
\hline & Female & Male & \\
\hline Selfing & 26 & 0 & $1: 0$ \\
\hline Heterosexual & 24 & 23 & $1: 1$ \\
\hline Homosexual & 28 & 0 & $1: 0$ \\
\hline
\end{tabular}

progenies (Table 2). The homosexual $\mathrm{F}_{1}$ progenies had higher $(74.5 \mathrm{~g})$ average fruit weight compared to that of heterosexual $F_{1}$ progenies $(68.0 \mathrm{~g})$ and parents $(68.8 \mathrm{~g}$; Table 2). Due to higher fruit weight, homosexual crosses also recorded higher yield $(2.28 \mathrm{~kg}$; Table 2$)$. In female homosexual crosses, yield performance of both parents could be seen, while yield potential of the male parents remained hidden in the heterosexual crosses. The results of the present study reflect that the female homosexual crosses can produce better progenies than heterosexual crosses. This contradicts some of the earlier findings: for example, Hossain et al. (1996) reported that female homosexual crosses did not produce better progenies than heterosexual crosses in kakrol (M. dioica).

\section{Sex expression in hybrid plants}

Out of 47 plants from the heterosexual cross, 24 were female and 23 male, showing 1:1 segregation of male and female plants. Seeds of female homosexual crosses produced $100 \%$ female plants in $\mathrm{F}_{1}$, indicating a female:male sex ratio of 1:0 (Table 3). These sex ratios indicated that the sex expression is controlled by $\mathrm{xx} / \mathrm{xY}$ chromosomes. However, Roy et al. (1966) reported no such differentiated chromosomes in Momordica. Therefore, it was concluded that the sex expression in sweet gourd is governed by a single gene, female being homozygous recessive and male being heterozygous.

In conclusion, the present study showed that female homosexual crossing is possible through the conversion of sex, and provides new opportunities for sweet gourd improvement. The technique presented in this study can be exploited in dioecious plant species to combine important characters of two female genotypes into a single plant. Since sweet gourd is vegetatively propagated, such a technique can lead to establish new varieties within a short period.

Acknowledgments The authors are highly thankful to Director ICAR Research Complex for NEH Region Umiam, Meghalaya for providing all the necessary field and laboratory facilities.

Open Access This article is distributed under the terms of the Creative Commons Attribution Noncommercial License which permits any noncommercial use, distribution, and reproduction in any medium, provided the original author(s) and source are credited.

\section{References}

Agresti A (2002) Categorical data analysis, 2nd edn. Wiley, Hoboken Ali M, Okubo H, Fujii T, Fujieda K (1991) Techniques for propagation and breeding of kakrol (Momordica dioica Roxb.). Sci Hortic 47:335-343

Atsmon D, Tabbak C (1979) Comparative effects of gibberellin, silver nitrate and aminoethoxyvinyl glycine on sexual tendency and ethylene evolution in the cucumber plant (Cucumis sativus L.). Plant Cell Physiol 20:1547-1555

Behera TK, Dey SS, Munshi AD, Gaikwad AB, Pal A, Singh I (2009) Sex inheritance and development of gynoecious hybrids in bitter gourd (Momordica charantia L.). Sci Hortic 120:130-133

Beyer E (1976) Silver ion: a potent antiethylene agent in cucumber and tomato. Hort. Sci 11:195-196

Das BK, Mukherjee SK (1986) Promotion of femaleness in Morus alba (L) by multiple application of plant growth regulators. Geobios 13:124-129

Durand R, Durand B (1991) Sex determination and reproductive organ differentiation in Mercurialis. Plant Sci 80:49-65

Ghaemi M, Sarrafi A, Alibert G (1994) The effects of silver nitrate, colchicines, cupric sulfate and genotype on the production of embryoids from anthers of tetraploid wheat (Triticum turgidum). Plant Cell. Tiss Org. Cult 36:355-359

Hallidri M (2004) Effect of silver nitrate on induction of staminate flowers in gynoecious cucumber lines (Cucumis sativus L.). Acta Hort 637:149-154

Heslop-Harrison J, Heslop-Harrison Y (1970) Evaluation of pollen viability by enzymatically induced fluorescence; intra cellular hydrolysis of fluorescein diacetate. Stain Tech. 45:115-120

Hossain MA, Islam M, Ali M (1996) Sexual crossing between two genetically female plants and sex genetics of kakrol (Momordica dioica Roxb.). Euphytica 90(1):121-125 
Hothorn T, Bretz F, Westfall P (2008) Simultaneous Inference inference in General general Parametric parametric Modelsmodels. Biometrical J. 50(3):346-363

Kozak M (2009) Analyzing one-way experiments: a piece of cake or a pain in the neck? Sci. Agr. 66(4):556-562

Marchetti S, Zampa C, Chiesa F (1992) Sex modification in Actinidia deliciosa var. Deliciosa Euphytica 64:205-213

Ockendon DJ, Clenagham R (1993) Effect of silver nitrate and 2, 4-D on anther culture of Brussels sprouts. Plant Cell Tiss Org Cult $32: 41-46$

Puzari NN (1999) Effect of plant growth regulators on quality traits of spine gourd (Momordica cochinchinensis Roxb.). Indian J Hill Farm 12:62-64

Rajput JC, Parulekar YR, Sawant SS, Jamadagni BM (1994) Sex modification in kartoli (Momordica dioica Roxb.) by foliar sprays of silver nitrate $\left(\mathrm{AgNO}_{3}\right)$. Curr. Sci 66:779

Ram D, Kalloo G, Banerjee MK (2002) Popularizing kakrol and kartoli: the indigenous nutritious vegetables. Indian Hort 9:6-9

Ram D, Kumar S, Singh M, Rai M, Kalloo G (2006) Inheritance of gynoecism in bitter gourd (Momordica charantia L.). J Hered 97:294-295
Robinson RW, Decker-Walters DS (1997) Cucurbits. CABI Publishing, Cambridge

Roy RP, Thakur V, Trivedi RN (1966) Cytogenetical studies in Momordica. J Cytol Genet 1:30-40

Sarkar D (2008) Lattice: multivariate data visualization with $\mathrm{R}$. Springer Science, New York

Stankovic L, Prodanovic S (2002) Silver nitrate effects on sex expression in cucumber (Cucumis sativus). II Balkan symposium on vegetables and potatoes. Acta Hort 47:579

Takahashi H, Jaffe MJ (1984) Further studies of auxin and ACC induced feminization in cucumber plant using ethylene inhibitors. Phyton 44:81-86

R Development Core Team (2010) R: a language and environment for statistical computing. R Foundation for Statistical Computing, Vienna, Austria; URL http://www.R-project.org, Accessed at 8 September 2010

Thomas TD (2008) The effect of in vivo and in vitro applications of ethrel and GA3 on sex ex-pression in bitter melon (Momordica charantia L.). Euphytica 164:317-323 